\title{
The Impact of Dreissenid Mussels on Growth of the Fragile Papershell (Leptodea fragilis), the Most Abundant Unionid Species in Lake Erie
}

\author{
Robert A. Krebs \\ Cleveland State University, r.krebs@csuohio.edu \\ Elizabeth M. Barkett \\ Cleveland State University \\ Matthew T. Begley \\ Cleveland State University
}

Follow this and additional works at: https://engagedscholarship.csuohio.edu/scibges_facpub

Part of the Biology Commons

How does access to this work benefit you? Let us know!

\section{Recommended Citation}

Krebs RA, Barkett EM, Begley MT. 2015. The impact of dreissenid mussels on growth of the fragile papershell (leptodea fragilis), the most abundant unionid species in lake erie. Can J Zool 93(2):143-8.

This Article is brought to you for free and open access by the Biological, Geological, and Environmental Sciences Department at EngagedScholarship@CSU. It has been accepted for inclusion in Biological, Geological, and Environmental Faculty Publications by an authorized administrator of EngagedScholarship@CSU. For more information, please contact library.es@csuohio.edu. 


\title{
The impact of dreissenid mussels on growth of the fragile papershell (Leptodea fragilis), the most abundant unionid species in Lake Erie
}

\author{
Robert A. Krebs, Elizabeth M. Barkett, and Matthew T. Begley
}

\begin{abstract}
The arrival of zebra mussels (Dreissena polymorpha (Pallas, 1771)) and subsequently quagga mussels (Dreissena bugensis Andrusov, 1897) (Dreissenidae) in the Great Lakes in the 1980s induced many changes, most notably the devastation of native freshwater mussel species. Recently, empty shells of the fragile papershell (Leptodea fragilis (Rafinesque, 1820)) have become common, particularly in the western basin of Lake Erie, suggesting that this fast-growing species may be increasing in numbers in the lake. To examine continued competition with dreissenids, shell age and length of L. fragilis were used to contrast lifespan and growth rate, estimated as the slope of age on shell length, for shells from two beach localities where byssal threads were present on most shells and two sites where dreissenids were rare or absent. Few recent shells from Lake Erie beaches exceeded 5 years of age, and byssal thread counts were more numerous on older shells. Growth and lifespan were estimated to be significantly lower where dreissenid mussels remained numerous than when measured either from historic collections along Lake Erie or from protected populations. Therefore, even for this early-reproducing species, competition from dreissenids may continue to interfere with growth and shorten lifespan, which are effects few other unionid species can likely tolerate sufficiently to sustain population growth.
\end{abstract}

Key words: competition, Dreissena, fragile papershell, growth rings, Leptodea fragilis, life history, shell size.

Résumé : L’arrivée des moules zébrées (Dreissena polymorpha (Pallas, 1771)) et, subséquemment, des moules quagga (Dreissena bugensis Andrusov, 1897) (dreissenidés) dans les Grands Lacs dans les années 1980 a induit de nombreux changements, dont le plus notable est la dévastation d'espèces de mulettes indigènes. Récemment, des coquilles vides de la leptodée fragile (Leptodea fragilis (Rafinesque, 1820)) sont devenues répandues, particulièrement dans le bassin occidental du lac Érié, donnant à penser que l'abondance de cette espèce à croissance rapide serait en expansion dans ce lac. Afin d'examiner la concurrence continue avec les dreissenidés, l'âge et la longueur de coquilles de L. fragilis ont été utilisés pour comparer la durée de vie et le taux de croissance, estimé comme étant la pente de l'âge par rapport à la longueur de la coquille, pour des coquilles provenant de deux sites de plage où des filaments de byssus étaient présents sur la plupart des coquilles et deux sites où les dreissenidés étaient rares ou absentes. Peu de coquilles récentes du lac Érié dépassaient l'âge de 5 ans, et le nombre de filaments de byssus était plus élevé sur les coquilles plus vieilles. Les estimations des taux de croissance et de la durée de vie étaient significativement plus faibles là où les dreissenidés demeuraient abondantes que dans des collections prélevées par le passé le long du lac Érié ou dans des populations protégées. Même pour cette espèce à reproduction précoce, la concurrence des dreissenidés pourrait donc continuer de nuire à la croissance et réduire la durée de vie, des effets que peu d'autres espèces d'unionidés peuvent vraisemblablement tolérer assez bien pour maintenir la croissance de leurs populations. [Traduit par la Rédaction]

Mots-clés : concurrence, Dreissena, leptodée fragile, anneaux de croissance, Leptodea fragilis, cycle biologique, taille de la coquille.

\section{Introduction}

The diverse fauna of native freshwater mussels (Bivalvia: Unionidae) in Lake Erie (Graf 2002) declined precipitously after the invasion of zebra (Dreissena polymorpha (Pallas, 1771)) and quagga (Dreissena bugensis Andrusov, 1897) mussels (Schloesser and Nalepa 1994; Schloesser et al. 1996). Nichols and Amberg (1999) argued that the destruction of native clams was likely the greatest ecological consequence of the dreissenid invasion. Shells of native species once littered beaches (Goodrich and Vander Schalie 1932) but largely disappeared by the 1990s (Schloesser et al. 1998). During the initial peak rise in dreissenid numbers in Lake Erie, thousands of attached dreissenids could be found on a single unionid mussel (Schloesser and Kovalak 1991; Schloesser and Masteller
1999), an effect correlated with unionid mortality (Schloesser and Kovalak 1991; Schloesser and Nalepa 1994; Ricciardi et al. 1996; Schloesser et al. 1998). By attaching to unionid valves, dreissenids hamper movement and burrowing, filter feeding, respiration, and reproduction (reviewed in Karatayev et al. 1997, 2002; Strayer 1999; Burlakova et al. 2000), they induce shell deformities (Lewandowski 1976; Hunter and Bailey 1992; Schloesser et al. 1996), and even reduce glycogen reserves in host unionids (Haag et al. 1993; Baker and Hornbach 1997; Sousa et al. 2011; Bódis et al. 2013).

In sum, the dreissenid presence may limit food availability whether dreissenids are attached or not (Baker and Levinton 2003), although the impact of variable dreissenid attachment has not been tested due to a lack of populations demonstrating vari- 
ation in infestation level. Ricciardi et al. (1995) suggest that a level of 100 dreissenids/unionid can kill. A greater focus has been placed on the conditions necessary to avoid competition (Nichols and Wilcox 1997; Zanatta et al. 2002; McGoldrick et al. 2009), but as dreissenid populations have begun to decline in the Great Lakes (Karatayev et al. 2002), shell numbers of a few unionid, and particularly the fragile papershell (Leptodea fragilis (Rafinesque, 1820)), have progressively increased along Lake Erie, at least within the western basin (Crail et al. 2011). Bryan et al. (2013) also reported hundreds of live young $L$. fragilis exposed on the lake bottom by seiches at the shallow far-western tip of Lake Erie, and by November 2012, empty shells were found on beaches as far east as Vermilion, Ohio $\left(41.427^{\circ} \mathrm{N}, 82.356^{\circ} \mathrm{W}\right)$. Understanding what now regulates the distribution of unionid mussels following such an environmental perturbation, like the introduction of a dreissenid species, is critical to predict the likelihood of persistence or extirpation of remaining species (Bogan 1993; Strayer et al. 2004). While most Lake Erie tributaries support mussels, and they show minimal populations of dreissenids, declines in diversity in rivers have also been common (Krebs et al. 2010).

The life-history variable of interest to mussel persistence is growth rate, although longevity is also predicted to change where dreissenids are present vs. absent, or where the abundance of dreissenids varies, which can be roughly estimated by the number of byssal thread bundles on fresh shells as an indicator of past attachment. That levels of dreissenid infestation correlate with field densities of dreissenids is established (Ricciardi et al. 1995), although byssal counts may underestimate the number of dreissenids attaching to $L$. fragilis because dreissenid mussels may also attach to earlier colonizers (clumping). This particularly holds for cases with high biofouling. Moreover, there may be spatiotemporal effects by variability in predation on dreissenids (Bowers and de Szalay 2007). Furthermore, whether fouling is by quagga mussels or by zebra mussels, the latter of which adhere more rapidly and tightly (Peyer et al. 2009), could influence physiological consequences to individual unionids (Burlakova et al. 2014).

Both shell age and growth rate may be estimated from growth lines, the latter as the regression coefficient $(\beta)$ of age on shell length (Ghent et al. 1978; Haag and Commens-Carson 2008; Haag 2012). Only shells of $L$. fragilis were sufficiently abundant to assess impacts of dreissenids, and this is the species for which Nichols and Amberg (1999) identified no changes in growth after the dreissenid invasion in Metzger Marsh, a protected wetland adjacent to Lake Erie where less than $1 \%$ of mussels possessed signs of zebra mussel encrustation. To contrast effects of dreissenid attachment, quantitative measurement of growth rates were made from several collections of fresh shells at two beaches in the western basin of Lake Erie and for two collections with low or no dreissenid presence: first pooled shell samples from protected habitats like marshes, river mouths, and other shallow zones in western Lake Erie, and second, shells from collections of L. fragilis from one of the same Lake Erie beaches made long before dreissenid mussels were introduced in North America. Dreissenids are predicted to slow unionid growth as an effect of presence versus absence, or by abundance both between populations and within populations. Basically, regression coefficients of age on shell length should be greater for collections of shells possessing fewer byssal threads.

\section{Materials and methods}

Large numbers of fresh empty shells of L. fragilis were collected near the Cedar Point section of the Ottawa National Wildlife Refuge (Ottawa NWR) at a locality called Potters Pond $\left(41.677^{\circ} \mathrm{N}\right.$, $83.306^{\circ} \mathrm{W}$ ) in 2008 and 2011 totaling 166 fresh dead L. fragilis and the public beach at Port Clinton $\left(41.515^{\circ} \mathrm{N}, 82.928^{\circ} \mathrm{W}\right)$ in 2011 and 2013 with 121 fresh dead. In all cases, individuals used for the study were collected as paired valves, the periostracum was yellow and not worn, and the nacre was shiny. For 26 shells pulled from icy waters in February of 2013 at Port Clinton, shells even contained remnants of tissue. Both of these sites are composed of vast flats of sand and mud, extending out from the beach with depth increasing only very gradually. The benthos at both locations was visibly unstable with ridges in the sand, and timed surveys by wading identified no live mussels in the shallow zones at Potters Pond and just one L. fragilis at Port Clinton (Zanatta et al. 2015). Thus, collected shells likely derived from populations that persist in deeper water or from young individuals living infaunally. Both lake sites lie near the outflows of small rivers, the Portage River at Port Clinton where many live mussels but no L. fragilis were collected, and Cedar Creek near Potters Pond, which is a dredged marina, from which just two mussels were found, one of which was L. fragilis. Across Lake Erie tributaries, L. fragilis is a minor component of the stream fauna (Prescott 2014; Zanatta et al. 2015).

Shell collections therefore provided the best indication of the lake fauna. The preserve permits very limited public access thus preserving available shells, and the Port Clinton site was surveyed in winter when Lake Erie reaches its lowest water level (http:// glakesonline.nos.noaa.gov/monitor.html), and collection of shells accumulating from early winter storms appeared to us to be unbiased by public beach access. During annual trips, we were alone on the beach collecting many shells half covered in snow, partially imbedded in ice, or exposed on sandbars offshore. The Cleveland Museum of Natural History possessed 246 L. fragilis shells collected in the western basin between the years 1943-1967. This period was long before dreissenid mussels arrived, but pollution levels may have been greater than currently observed (Regier and Hartman 1973; Allinger and Reavie 2013). Another 32 recently collected empty shells (2010-2011) were available from the flooded river mouths of Crane Creek $\left(41.626^{\circ} \mathrm{N}, 83.209^{\circ} \mathrm{W}\right)$, Turtle Creek $\left(41.604^{\circ} \mathrm{N}, 83.153^{\circ} \mathrm{W}\right)$, and Old Woman Creek $\left(41.380^{\circ} \mathrm{N}\right.$, $82.512^{\circ} \mathrm{W}$ ), as a second contrast to growth in the absence of the invasive dreissenids, although water temperatures were warmer.

For each shell, the left valve was measured $(\mathrm{cm})$ and the age estimated from growth ring counts (Rypel et al. 2008), a procedure that has been well validated (Haag and Commens-Carson 2008), particularly in L. fragilis (Nichols and Amberg 1999). Byssal thread abundance was categorized at three levels (i.e., 0-5 byssal thread bundles, 6-10 byssal thread bundles, and 11+ byssal thread bundles), as Nichols and Amberg (1999) used these same categories of the number of live dreissenids in their study at Metzger Marsh. Therefore, one-way ANCOVA in PAST version 3.0 (Hammer et al. 2001) and linear regression of age on shell length was applied to estimate the slope of the line, which is a surrogate for growth rate. Analyses were run twice for the marsh-collected shells and the historic specimens, first on all data with age log-transformed to linearize results in analyses that included older individuals (Sansom et al. 2013), and second, to restrict results to shells aged six and under, as growth slows with age making data nonlinear (Nichols and Amberg 1999; Haag 2012). No modern shells from beaches exceeded 6 years in age, so restricting age classes also placed all data sets within the same age groups. Another set of analyses assessed effect of infestation rate contrasting the three byssal thread abundance groups (0-5, 6-10, and $11+)$, assessing age and slope of age on shell length in ANCOVA.

\section{Results}

The relationship between age, which was log-transformed, and length in L. fragilis varied significantly across space and time (test of homogeneity of slopes, $\left.F_{[3,561]}=14.6, p<0.0001\right)$ : Ottawa NWR: $y=6.3 x+4.7, r^{2}=0.49$; Port Clinton: $y=5.9 x+4.6, r^{2}=0.54$; river mouths and marshes: $y=10.3 x+5.3, r^{2}=0.73$; historical collections at Port Clinton: $y=9.6 x+2.2, r^{2}=0.65$. Difference in slopes for the relationship of age on shell length was not significant between 
Fig. 1. The relationship between shell age and shell length for fragile papershells (Leptodea fragilis) collected in (A) various marshes and river mouths between 2008 and 2013 and (B) along the beach at Port Clinton, Ohio, between 1943 and 1967.

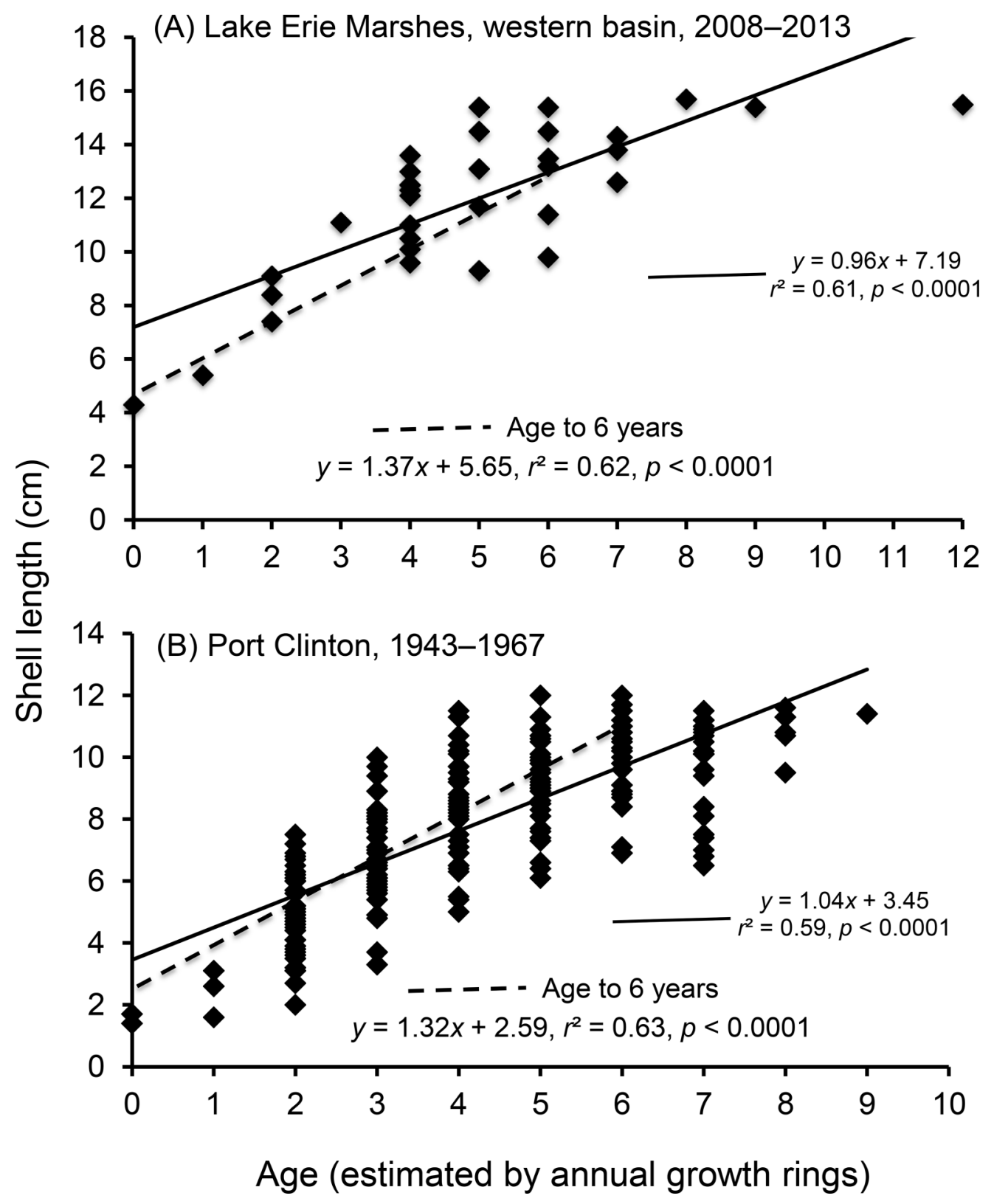

the dreissenid-exposed areas, the two recent-day collections from Lake Erie beaches $\left(F_{[1,284]}=0.34, p=0.55\right)$, or between the two low or no dreissenid areas (Figs. $1 \mathrm{~A}, 1 \mathrm{~B} ; \mathrm{F}_{[1,276]}=0.31, p=0.58$ ).

Mean age also varied among the four L. fragilis collections (assessing age in ANCOVA, $\left.F_{[3,561]}=140, P<0.0001\right)$. For age, the difference between the two dreissenid-exposed areas, the Ottawa NWR and Port Clinton sets of shells (Figs. 2A-2F), approached significance $\left(F_{[1,284]}=6.33, p=0.051 ; 2.9\right.$ years at Port Clinton, 2.2 years at Ottawa NWR), and the mean age of shells in the recent marsh collections (at 4.9 years) was significantly greater than the mean age of shells from the historical Port Clinton collection (4.1 years, $F_{[1,276]}=177, p<0.0001$ ). However, the majority of the variation was between areas exposed to more dreissenid mussels and areas protected from or pre-dating the dreissenid presence. Just $1 \%$ of the L. fragilis shells were scored as 6 years old (Figs. $2 \mathrm{~A}-2 \mathrm{~F})$, in the marshes and river mouths, $36 \%$ were over 5 years of age, with a maximum age of 12 , and $22 \%$ of the shells from the historical data set from Port Clinton were over 5 years of age, with a maximum age of 10 (Figs. 1A, 1B).

Within populations exposed to dreissenids, a reduction in the regression coefficient of age on length occurred for individuals burdened with a larger number of dreissenids, based on byssal thread bundles found on shells (Figs. 2A-2F, results presented on untransformed data). Those individuals at the Ottawa NWR with few (Fig. 2A) or only a small number of byssal threads (Fig. 2B) compared with those with more byssal threads (Fig. 2C) possessed a significantly larger slope of age on shell length $\left(F_{[2,162]}=3.54\right.$, $p=0.031$ ). While variation among the three groups was not significant for the Port Clinton collections $\left(F_{[2,117]}=0.85, p=0.43\right)$, trends were in the same direction as for collections at the Ottawa NWR, because the highest byssal thread category had the lowest slope (contrasting regressions in Figs. 2D-2E), and 67\% of all shells from Port Clinton possessed $>10$ byssal thread bundles but only $34 \%$ of 
Fig. 2. The relationship between shell age and shell length for fragile papershells (Leptodea fragilis) collected at two sites on the south coast of Lake Erie in Ohio: the Ottawa National Wildlife Refuge $(\mathrm{A}-\mathrm{C})$ and the public beach at Port Clinton (D-F). Results were separated by byssal thread abundance on collected shells that was categorized at three levels: 0-5 byssal thread bundles (A and D), 6-10 byssal thread bundles (B and $\mathrm{E})$, and 11+ byssal thread bundles (C and F).
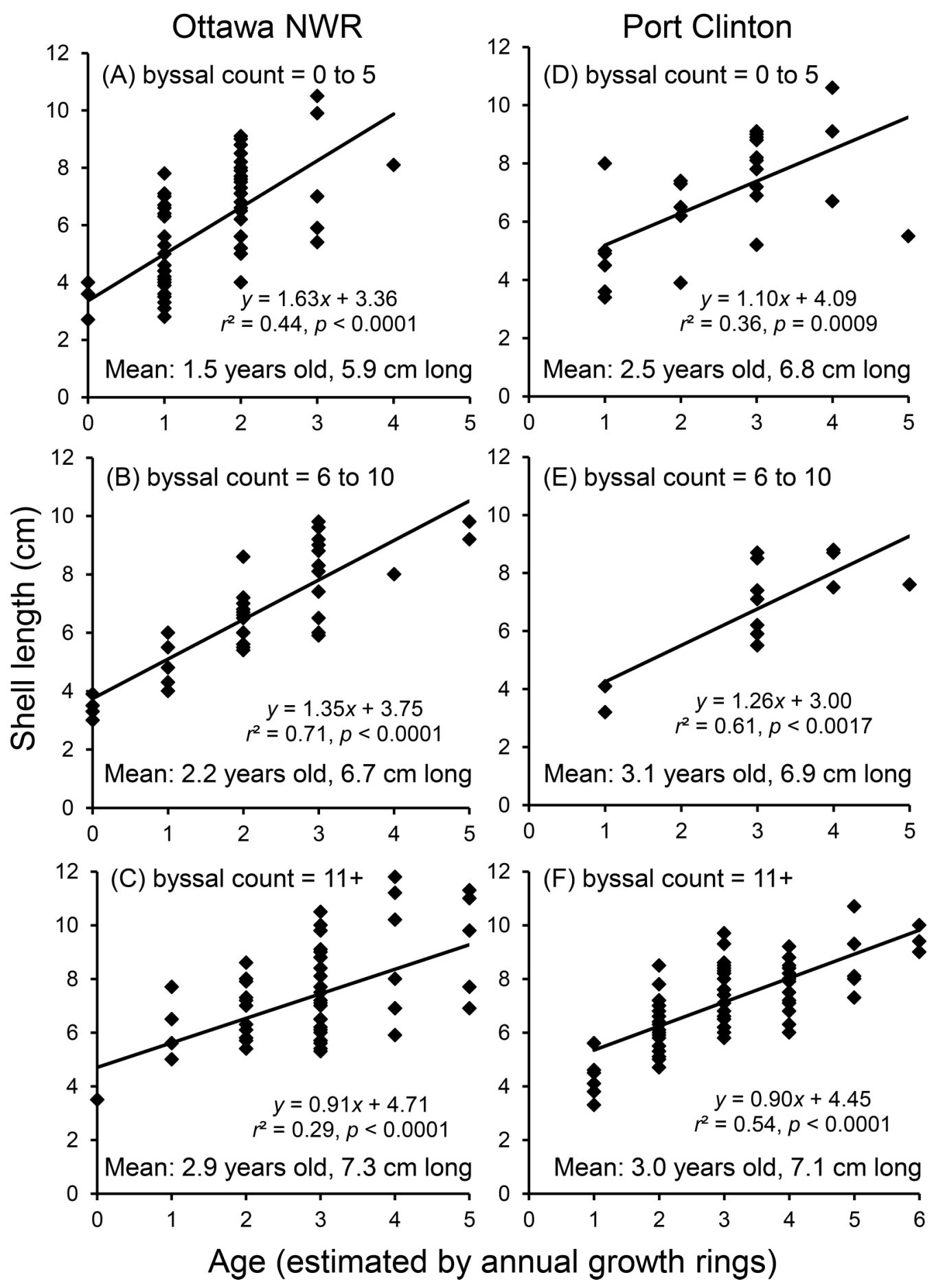

shells from the Ottawa NWR had this number of byssal thread bundles.

\section{Discussion}

Living in the presence of dreissenid mussels in Lake Erie comes with costs to individuals of L. fragilis, and as Nichols and Amberg (1999) observed, this cost may be avoided or reduced for mussels living in marshes or other protected areas like stream mouths.
These shallow areas appear to provide a refuge from dreissenids even today (Zanatta et al. 2015), especially as the growing dominance of quagga mussels over zebra mussels may be relaxing the competitive interactions that have been so damaging to communities of native unionid mussels (Ricciardi et al. 1995; Schloesser et al. 1998; Burlakova et al. 2014). In addition, the relationship among shell size, growth rings, and byssal thread counts suggest multiple effects on life history even on the one species that may 
sustain reasonable levels of abundance in the open waters of Lake Erie (Bryan et al. 2013, 2014). Age structure inferred from recently collected empty shells shifted to younger individuals in the populations exposed to large numbers of dreissenid mussels and growth has slowed. Haag (2012) reports this species already to be an anomaly within the Unionidae for a short average life of just 5 years and an ability to reproduce in its first year. Our evidence suggests that in the presence of dreissenids, few individuals live to an age of 5 (mean age of shells was less than 3 years), while the mean age of shells collected in the marsh and those of historical collections from Lake Erie averaged over 4 years. Perhaps the younger age of the L. fragilis shells in historical Port Clinton collections relates to the poor water quality of Lake Erie between 1950 and 1970 (Yuan et al. 2014) that damaged benthic communities, especially of mayflies (Britt 1955). As noted, growth rate in L. fragilis remained similar to the later marsh collections.

Although not every contrast made among the four sets of shells or among different groups based on byssal thread number was individually significant, most were, and each contrast produced the same predicted pattern of decline with either dreissenid presence or an increase in dreissenid numbers; shell size of L. fragilis increased more slowly with age for populations living with abundant dreissenids than in marshes or when present in the lake before the dreissenid invasion. Shell growth was particularly slow for shells on which byssal thread counts were in the highest group, although that pattern was highlighted only at the Ottawa NWR where dreissenid encrustation was relatively less than at Port Clinton. Basically, the much higher infestation rate at Port Clinton was associated with fewer young or small individuals that were free of byssal threads. A high abundance of dreissenids may limit growth of all individuals whether they were directly infested or not infested at all (Haag et al. 1993; Strayer and Smith 1996).

None of these results are surprising, but they do provide evidence of the mechanism by which dreissenids limit the return of communities of native mussels. Baker and Levinton (2003) reported that dreissenids compete with unionids for food even where direct infestation of individuals does not occur. Young unionids may escape this competition for a while, as they feed infaunally within the substrate (Yeager et al. 1994). Only as mussels become larger must they expose themselves at the surface and feed in the water column, and active water exchange is required for reproduction (Vaughn and Hakenkamp 2001). Thus, selection may start favoring a shift in life history to a more opportunistic mode, sensu Haag (2012): a short lifespan, low age at maturity, moderate to very high fecundity, long-term brooding, and a fast growth rate. But no change in extant populations will occur rapidly. Instead, L. fragilis and the giant floater (Pyganodon grandis (Say, 1829)), the two fastest growing unionid species (Haag and Rypel 2011), make up the majority of the shells on beaches (Crail et al. 2011), with the most predominant being L. fragilis, whose females become gravid by age 1 and produce more glochidia than any other unionid species (Haag 2012, pp. 195-197). The unique combination of all these traits may enable them to remain abundant where dreissenids are present, yet even for this species, fresh shells disappeared by the early 1990s (Schloesser and Nalepa 1994), and they were uncommon along the coast until about 2004, after which their numbers slowly increased (Crail et al. 2011).

Still, searches of the lake bottom out from the shorelines at both Port Clinton and the Ottawa NWR (Zanatta et al. 2015) produced just one live individual (a L. fragilis). That L. fragilis remains at low relative abundance in unionid communities in rivers where dreissenids are rare (Prescott 2014; Zanatta et al. 2015) suggests that the source of shells is not nearby rivers. Furthermore, L. fragilis has been listed historically as a common member of the deep water (>5 m) Lake Erie community (Wood 1953, 1963; Carr and Hiltunen 1965), and its light-shelled morphology also suggests adaptation to deep water within lakes (Ghent et al. 1978).
Other changes to the lake environment potentially have improved opportunities for L. fragilis to increase. Freshwater drum (Aplodinotus grunniens Rafinesque, 1819), the putative and only proposed host species of L. fragilis (Watters et al. 2009), has become very abundant based on fishing reports that suggest increases in abundance lake-wide starting around 2006 despite declines in many other fish species (ODW 2013). This fish once preferentially fed on midges (Chironomidae) (Bur 1982) and now regularly consumes zebra mussels in Lake Erie (Morrison et al. 1997).

Other unionids also persist, including pink heelsplitter (Potamilus alatus (Say, 1817)), deertoe (Truncilla truncata Rafinesque, 1820), and fawnsfoot (Truncilla donaciformis (I. Lea, 1828)), which also use freshwater drum as a host fish, but they are present in much lower numbers (Crail et al. 2011; Zanatta et al. 2015), and whether they reproduce in the lake or are found as migrants from coastal refuges is not known. Sustaining high abundance requires growth beyond reproductive maturity to enable sufficient reproduction in the presence of dreissenids.

\section{Acknowledgements}

This research was supported by the Lake Erie Protection Fund (SG 390-10) and the US Fish and Wildlife Service (\#30181AG15). E.M.B. was supported by the Cleveland State University Engaged Learning Award Program. T. Prescott helped to collect specimens and J. Waggoner sent photographs of L. fragilis from a beach in Vermilion, Ohio, in late 2012.

\section{References}

Allinger, L.E., and Reavie, E.D. 2013. The ecological history of Lake Erie as recorded by the phytoplankton community. J. Gt. Lakes Res. 39(3): 365-382. doi:10.1016/j.jglr.2013.06.014.

Baker, S.M., and Hornbach, D.J. 1997. Acute physiological effects of zebra mussel (Dreissena polymorpha) infestation on two unionid mussels, Actinonaias ligamentina and Amblema plicata. Can. J. Fish. Aquat. Sci. 54(3): 512-519. doi:10.1139/ f96-319.

Baker, S.M., and Levinton, J.S. 2003. Selective feeding by three native North American freshwater mussels implies food competition with zebra mussels. Hydrobiologia, 505(1-3): 97-105. doi:10.1023/B:HYDR.0000007298.52250.99.

Bódis, E., Tóth, B., and Sousa, R. 2013. Impact of Dreissena fouling on the physiological condition of native and invasive bivalves: interspecific and temporal variations. Biol. Invasions, 16(7): 1373-1386. doi:10.1007/s10530-013-0575-Z.

Bogan, A.E. 1993. Freshwater bivalve extinctions (Mollusca: Unionidae): a search for causes. Am. Zool. 33(6): 599-609. doi:10.1093/icb/33.6.599.

Bowers, R.W., and de Szalay, F.A. 2007. Fish predation of zebra mussels attached to Quadrula quadrula (Bivalvia: Unionidae) and benthic molluscs in a Great Lakes coastal wetland. Wetlands, 27(1): 203-208. doi:10.1672/0277-5212(2007) 27[203:FPOZMA]2.0.CO;2.

Britt, N.W.1955. Stratification in western Lake Erie in summer of 1953: effects on the Hexagenia (Ephemeroptera) population. Ecology, 36: 239-244. doi:10.2307| 1933229.

Bryan, N.J., Florence, C.V., Crail, T.D., and Moorhead, D.L. 2013. Freshwater mussel community response to warm water discharge in western Lake Erie. J. Gt. Lakes Res. 39(3): 449-454. doi:10.1016/j.jglr.2013.06.007.

Bryan, N.J., Moorhead, D.L., and Crail, T.D. 2014. Habitat characteristics of a unionid refuge in the thermal plume of a power plant in western Lake Erie. J. Gt. Lakes Res. 40(3): 699-704. doi:10.1016/j.jglr.2014.05.015.

Bur, M.T. 1982. Food of freshwater drum in western Lake Erie. J. Gt. Lakes Res. 8(4): 672-675. doi:10.1016/S0380-1330(82)72007-6.

Burlakova, L.E., Karatayev, A.Y., and Padilla, D.K. 2000. The impact of Dreissena polymorpha (Pallas) invasion on unionid bivalves. Int. Rev. Hydrobiol. 85(5-6): 529-541. doi:10.1002/1522-2632(200011)85:5/6<529::AID-IROH529>3.0.CO;2-O.

Burlakova, L.E., Tulumello, B.L., Karatayev, A.Y., Krebs, R.A., Schloesser, D.W., Paterson, W.L., Griffith, T.A., Scott, M.W., Crail, T., and Zanatta, D.T. 2014. Competitive replacement of invasive congeners may relax impact on native species: interactions among zebra, quagga, and native unionid mussels. PLoS ONE. doi:10.1371/journal.pone.0114926.

Carr, J.F., and Hiltunen, J.K. 1965. Changes in the bottom fauna of western Lake Erie from 1930 to 1961. Limnol. Oceanogr. 10(4): 551-569. doi:10.4319/1o.1965. 10.4.0551.

Crail, T.D., Krebs, R.A., and Zanatta, D.T. 2011. Unionid mussels from nearshore zones of Lake Erie. J. Gt. Lakes Res. 37(1): 199-202. doi:10.1016/j.jglr.2010.12. 006 .

Ghent, A.W., Singer, R., and Johnson-Singer, L. 1978. Depth distributions determined with SCUBA, and associated studies of the freshwater unionid clams Elliptio complanata and Anodonta grandis in Lake Bernard, Ontario. Can. J. Zool. 56(8): 1654-1663. doi:10.1139/z78-228.

Goodrich, C., and Vander Schalie, H. 1932. I. On an increase in the naiad fauna of 
Saginaw Bay, Michigan. II. The naiad species of the Great Lakes. Occas. Pap. Mus. Zool. Univ. Mich. 238: 1-14. Available from http://deepblue.lib.umich. edu/handle/2027.42/56677 [accessed 19 July 2014].

Graf, D.L. 2002. Historical biogeography and late glacial origin of the freshwater pearly mussel (Bivalvia: Unionidae) faunas of Lake Erie, North America. Mus. Comp. Zool. Occas. Pap. Mollusc. 6: 175-210.

Haag, W.R. 2012. North American freshwater mussels: natural history, ecology, and conservation. Cambridge University Press, New York.

Haag, W.R., and Commens-Carson, A.M. 2008. Testing the assumption of annual shell ring deposition in freshwater mussels. Can. J. Fish. Aquat. Sci. 65(3): 493-508. doi:10.1139/f07-182.

Haag, W.R., and Rypel, A.L. 2011. Growth and longevity in freshwater mussels: evolutionary and conservation implications. Biol. Rev. 86(1): 225-247. doi:10. 1111/j.1469-185X.2010.00146.x. PMID:20608928.

Haag, W.R., Berg, D.J., Garton, D.W., and Farris, J.L. 1993. Reduced survival and fitness in native bivalves in response to fouling by the introduced zebra mussel (Dreissena polymorpha) in western Lake Erie. Can. J. Fish. Aquat. Sci. 50(1): 13-19. doi:10.1139/f93-002.

Hammer, Ø., Harper, D.A.T., and Ryan, P.D. 2001. PAST: Paleontological statistics software package for education and data analysis. Palaeontol. Electron. vol. 4, article 4. Available from http://folk.uio.no/ohammer/past/ [accessed 1 June 2014].

Hunter, R.D., and Bailey, J.F. 1992. Dreissena polymorpha (zebra mussel): colonization of soft substrata and some effects on unionid bivalves. Nautilus, 106(2): 60-67.

Karatayev, A.Y., Burlakova, L.E., and Padilla, D.K. 1997. The effects of Dreissena polymorpha (Pallas) invasion on aquatic communities in eastern Europe. J. Shell. Res. 16(1): 187-203.

Karatayev, A.Y., Burlakova, L.E., and Padilla, D.K. 2002. Impacts of zebra mussels on aquatic communities and their role as ecosystem engineers. In Invasive aquatic species of Europe: distribution, impacts and management. Edited by E. Leppakoski, S. Gollach, and S. Olenin. Kluwer Academic Publishers, Dordrecht, the Netherlands. pp. 433-446.

Krebs, R.A., Borden, W.C., Steiner, E.R., Lyons, M.S., Zawiski, W., and Walton, B.M. 2010. Determinants of mussel diversity in Lake Erie tributaries. J. N. Am. Benthol. Soc. 29(2): 506-520. doi:10.1899/09-017.1.

Lewandowski, K. 1976. Unionidae as a substratum for Dreissena polymorpha. Pol. Arch. Hydrobiol. 23(3): 409-420.

McGoldrick, D.J., Metcalfe-Smith, J.L., Arts, M.T., Schloesser, D.W., Newton, T.J., Mackie, G.L., Monroe, E.M., Biberhofer, J., and Johnson, K. 2009. Characteristics of a refuge for native freshwater mussels (Bivalvia: Unionidae) in Lake St. Clair. J. Gt. Lakes Res. 35(1): 137-146. doi:10.1016/j.jglr.2008.11.007.

Morrison, T.W., Lynch, W.E., Jr., and Dabrowski, K. 1997. Predation on zebra mussels by freshwater drum and yellow perch in western Lake Erie. J. Gt. Lakes Res. 23(2): 177-189. doi:10.1016/S0380-1330(97)70895-5.

Nichols, S.J., and Amberg, J. 1999. Co-existence of zebra mussels and freshwater unionids: population dynamics of Leptodea fragilis in a coastal wetland infested with zebra mussels. Can. J. Zool. 77(3): 423-432. doi:10.1139/z98-241.

Nichols, S.J., and Wilcox, D.A. 1997. Burrowing saves Lake Erie clams. Nature, 389: 921. doi:10.1038/40039.

Ohio Division of Wildlife (ODW). 2013. Ohio's Lake Erie Fisheries, 2012. Annual status report. Federal aid in fish restoration project F-69-P. Ohio Department of Natural Resources, Division of Wildlife, Lake Erie Fisheries Units, Fairport and Sandusky. Available from http://wildlife.ohiodnr.gov/portals/wildlife/ pdfs/lakeeriestatusreport.pdf [accessed 14 December 2014].

Peyer, S.M., McCarthy, A.J., and Lee, C.E. 2009. Zebra mussels anchor byssal threads faster and tighter than quagga mussels in flow. J. Exp. Zool. 212: 2027-2036. doi:10.1242/jeb.028688.

Prescott, T.J. 2014. Assessment of freshwater mussel communities of small stream mouths along Lake Erie. M.Sc. thesis, Department of Biological, Geological and Environmental Sciences, Cleveland State University, Cleveland, Ohio.

Regier, H.A., and Hartman, W.L. 1973. Lake Erie's fish community: 150 years of cultural stresses. Science, 180: 1248-1255. doi:10.1126/science.180.4092.1248. PMID:17759111.

Ricciardi, A., Rasmussen, J.B., and Whoriskey, F.G. 1995. Predicting the intensity and impact of Dreissena infestation on native unionid bivalves from Dreissena field density. Can. J. Fish. Aquat. Sci. 52(7): 1449-1461. doi:10.1139/f95-140.

Ricciardi, A., Whoriskey, F.G., and Rasmussen, J.B. 1996. Impact of the Dreissena invasion on native unionid bivalves in the upper St. Lawrence River. Can. J. Fish. Aquat. Sci. 53(6): 1434-1444. doi:10.1139/f96-068.

Rypel, A.L., Haag, W.R., and Findlay, R.H. 2008. Validation of annual growth rings in freshwater mussel shells using cross dating. Can. J. Fish. Aquat. Sci. 65(10): 2224-2232. doi:10.1139/F08-129.

Sansom, B.J., Hornbach, D.J., Hove, M.C., and Kilgore, J.S. 2013. Effects of flow restoration on mussel growth in a wild and scenic North American river. Aquat. Biosyst. 9(1): 6. doi:10.1186/2046-9063-9-6.

Schloesser, D.W., and Kovalak, W.P. 1991. Infestation of unionids by Dreissena polymorpha in a power plant canal in Lake Erie. J. Shellfish Res. 10(2): 355-359.

Schloesser, D.W., and Masteller, E.C. 1999. Mortality of unionid bivalves (Mollusca) associated with dreissenid mussels (Dreissena polymorpha and D. bugensis) in Presque Isle Bay, Lake Erie. Northeast. Nat. 6(4): 341-352. doi:10.2307| 3858274.

Schloesser, D.W., and Nalepa, T.F. 1994. Dramatic decline of unionid bivalves in offshore waters of western Lake Erie after invasion by the zebra mussel, Dreissena polymorpha. Can. J. Fish. Aquat. Sci. 51(10): 2234-2242. doi:10.1139/ f94-226.

Schloesser, D.W., Nalepa, T., and Mackie, G. 1996. Zebra mussel infestation of unionid bivalves (Unionidae) in North America. Am. Zool. 36(3): 300-310. doi:10.1093/icb/36.3.300.

Schloesser, D.W., Kovalak, W.P., Longton, G.D., Ohnesorg, K.L., and Smithee, R.D. 1998. Impact of zebra and quagga mussels (Dreissena spp.) on freshwater unionids (Bivalvia: Unionidae) in the Detroit River of the Great Lakes. Am. Midl. Nat. 140(2): 299-313. doi:10.1674/0003-0031(1998)140[0299: IOZAQM]2.0.CO;2.

Sousa, R., Pilotto, F., and Aldridge, D.C. 2011. Fouling of European freshwater bivalves (Unionidae) by the invasive zebra mussel (Dreissena polymorpha). Freshw. Biol. 56(5): 867-876. doi:10.1111/j.1365-2427.2010.02532.x.

Strayer, D.L. 1999. Effects of alien species on freshwater mollusks in North America. J. N. Am. Benthol. Soc. 18(1): 74-98. doi:10.2307/1468010.

Strayer, D.L., and Smith, L.C. 1996. Relationships between zebra mussels (Dreissenia polymorpha) and unionid clams during the early stages of the zebra mussel invasion of the Hudson River. Freshw. Biol. 36(3): 771-779.

Strayer, D.L., Downing, J.A., Haag, W.R., King, T.L., Layzer, J.B., Newton, T.J., and Nichols, S.J. 2004. Changing perspectives on pearly mussels, North America's most imperiled animals. Bioscience, 54(5): 429-439. doi:10.1641/0006-3568 (2004)054[0429:CPOPMN]2.0.CO;2.

Vaughn, C.C., and Hakenkamp, C.C. 2001. The functional role of burrowing bivalves in freshwater ecosystems. Freshw. Biol. 46(11): 1431-1446. doi:10.1046| j.1365-2427.2001.00771.x.

Watters, G.T., Hoggarth, M.A., and Stansbery, D.H. 2009. The freshwater mussels of Ohio. The Ohio State University Press, Columbus.

Wood, K.G. 1953. Distribution and ecology of certain bottom-living invertebrates of the western basin of Lake Erie. Ph.D. dissertation, Great Lakes Research Division, University of Michigan, Ann Arbor.

Wood, K.G. 1963. The bottom fauna of western Lake Erie. Univ. Mich. Gt. Lakes Res. Div. Publ. No. 10. University of Michigan, Ann Arbor. pp. 258-265.

Yeager, M.M., Cherry, D.S., and Neves, R.J. 1994. Feeding and burrowing behaviors of juvenile rainbow mussels, Villosa iris (Bivalvia: Unionidae). J. N. Am. Benthol. Soc. 13(2): 217-222. doi:10.2307/1467240.

Yuan, F., Depew, R., and Soltis-Muth, C. 2014. Ecosystem regime change inferred from the distribution of trace metals in Lake Erie sediments. Sci. Rep. 4: 7265. doi:10.1038/srep07265. PMID:25434300.

Zanatta, D.T., Mackie, G.L., Metcalfe-Smith, J.L., and Woolnough, D.A. 2002. A refuge for native freshwater mussels (Bivalvia: Unionidae) from impacts of the exotic zebra mussel (Dreissena polymorpha) in Lake St. Clair. J. Gt. Lakes Res. 28(3): 479-489. doi:10.1016/S0380-1330(02)70599-6.

Zanatta, D.T., Bossenbroek, J., Burlakova, L.E., Crail, T., de Szalay, F., Griffith, T.A., Kapusinski, D., Karateyev, A.Y., Krebs, R.A., Meyer, E.S., Paterson, W.L., Prescott, T.J., Rowe, M.T., Schloesser, D.W., and Walsh, M.C. 2015. Distribution of native mussel (Unionidae) assemblages in coastal Lake Erie, Lake St. Clair, and connecting channels, twenty-five years after the dreissenid invasion. Northeast. Nat. In press. 